e-ISSN. 2685-7650

Vol. 1 No. 2 (2019), pp 82-89

DOI: https://doi.org/10.33366/jkn.v1i2.24

\title{
Strategi Komunikasi Pemasaran Sentra Tenun Prailiu dalam Meningkatkan Penjualan Kain Tenun Sumba Timur
}

\author{
Ririn Rambu Babang ${ }^{1}$, Asfira Rachmad Rinata ${ }^{2}$ \\ ${ }^{1,2}$ Program Studi Ilmu Komunikasi, Universitas Tribhuwana Tunggadewi \\ Email: patihririn2015@gmail.com
}

\begin{abstract}
Woven fabric is a handicraft product inherited from generation to generation. Woven fabric can be weared as dress in dances at parties or in traditional events. Every motif on woven fabric has meaning both traditionally and culturally. The purpose of this study is to find out the marketing strategy and the factors that influence it. The method used in this research is descriptive qualitative method with data collection techniques using the method of interview, observation, documentation to obtain primary data and secondary data. As well as data analysis techniques carried out through reduction, presentation and drawing conclusions. The result shows that implementation of marketing communication strategies Prailiu Weaving Center uses a marketing mix consisting of product, price, place and promotion which includes sales promotion, face-to-face promotion and direct marketing. The marketing strategy of the Prailiu Weaving Center consists of marketing strategy analysis which includes opportunity analysis and competitive analysis, as well as the marketing process which consists of determining product segmentation, targeting and positioning. Factors that influence marketing activities consist of supporting factors and inhibiting factors from both internal and external environments.
\end{abstract}

Keywords: Strategy, Marketing Commuication, Woven Fabric

\begin{abstract}
Abstrak: Kain tenun merupakan produk kerajinan tangan yang diwariskan dari generasi ke generasi. Kain ini dapat dipakai sebagai busana tari-tarian dalam pesta ataupun acara adat. Setiap motif pada kain tenun memiliki makna baik secara adat maupun budaya. Tujuan penelitian ini adalah untuk mengetahui strategi pemasaran serta faktor-faktor yang mempengaruhi. Metode yang digunakan dalam penelitian ini adalah metode deskriptif kualitatif dengan teknik pengambilan data menggunakan metode wawancara, observasi, dan dokumentasi untuk mendapatkan data primer dan data sekunder. Teknik analisis data dilakukan dengan cara reduksi, sajian dan penarikan kesimpulan. Hasil penelitian menunjukkan bahwa penerapan strategi komunikasi pemasaran Sentra Tenun Prailiu menggunakan bauran pemasaran yang terdiri dari product, price, place dan promotion yang meliputi promosi penjualan, promosi tatap muka dan direct marketing. Strategi pemasaran Sentra Tenun Prailiu terdiri dari analisis strategi pemasaran yang meliputi analisis peluang dan analisis kompetitif, serta proses pemasaran yang terdiri dari penentuan segmentasi, targeting dan positioning produk. Faktor yang mempengaruhi kegiatan pemasaran terdiri dari faktor pendukung dan faktor penghambat baik dari lingkungan internal maupun eksternal.
\end{abstract}

Kata Kunci : Strategi, Komuikasi Pemasaran, Kain Tenun

\section{Pendahuluan}

Komunikasi pemasaran adalah usaha untuk menyampaikan pesan kepada publik terutama konsumen mengenai produk/jasa yang ditawarkan. Komunikasi pemasaran memiliki peran yang sangat penting bagi perusahaan untuk membangun citra (image) suatu merek tertentu. Selain itu komunikasi pemasaran dapat membentuk kesadaran konsumen terhadap produk/jasa yang dihasilkan perusahaan, sehingga konsumen mengenal produk/jasa tersebut. Komunikasi pemasaran dapat merangsang terjadinya penjualan. Komunikasi pemasaran lebih menekankan pada pemenuhan secara langsung produk atau jasa yang diperlukan konsumen. Dengan demikian pemasaran senantiasa berupaya untuk meningkatkan hubungan pertukaran ekonomi antara organisasi dan konsumen. 


\section{Jurnal Komunikasi Nusantara}

e-ISSN. 2685-7650

Vol. 1 No. 2 (2019), pp 82-89

DOI: https://doi.org/10.33366/jkn.v1i2.24

Definisi lain dari komunikasi pemasaran yaitu faktor pendorong untuk meningkatkan penjualan sehingga tujuan perusahaan dapat tercapai. Pengetahuan mengenai komunikasi pemasaran menjadi penting bagi perusahaan pada saat dihadapkan pada beberapa permasalahan, seperti menurunnya pendapatan perusahaan yang disebabkan oleh menurunnya daya beli konsumen terhadap suatu jasa yang mengakibatkan lambatnya pertumbuhan dan perkembangan perusahaan (Maryanto \& Syahida, 2019). Komunikasi pemasaran dibutuhkan sebagai elemen penting yang tidak bisa dipisahkan dari dunia bisnis (Sutisna 2010: 5).

Komunikasi pemasaran berfungsi sebagai perantara dan pertukaran nilai suatu produk antara perusahaan dengan konsumen agar keduanya saling menguntungkan. Komunikasi pemasaran memiliki peran yang sangat penting sebagai persaingan antar bisnis atau perusahaan, bahkan bagaimana perusahaan memiliki cara agar perusahaan tersebut memiliki loyalitas dan kepuasan di mata konsumen. Komunikasi pemasaran merupakan kegiatan yang sangat penting dalam dunia usaha. Dalam kondisi usaha seperti sekarang ini, usaha yang kita dirikan bukanlah satu-satunya usaha dengan model dan tampilan seperti demikian. Banyak perusahaan di luar sana yang memiliki usaha yang mungkin hampir sama dengan usaha yang kita dirikan (Kotler dan keller 2008:172).

Salah satu produk kearifan lokal yang fenomenal di Provinsi Nusa Tenggara Timur, khususnya di Sumba Timur adalah Kain Tenun Ikat. Kain tenun ikat merupakan produk kerajinan tangan yang sudah diwariskan sejak jaman dahulu. Produk lokal yang menjadi kebanggaan ini memiliki makna tersendiri bagi masyarakat di Sumba Timur, baik secara adat maupun budaya. Berbagai motif pada tenun ikat mempunyai daya tarik yang kuat, baik bagi masyarakat Lokal maupun Wisatawan.

Secara adat dan budaya, tenun ikat tradisional Sumba Timur memiliki banyak fungsi. Pada umumnya tenun ikat ini digunakan sebagai busana yang dipakai dalam tari-tarian pada pesta/upacara adat, sebagai alat penghargaan dan pemberian perkawinan (mas kawin), sebagai alat penghargaan dan pemberi andalan acara kematian, sebagai denda adat untuk mengembalikan keseimbangan sosial yang terganggu (fungsi hukum), sebagai mitos yaitu lambang suku yang diagungkan karena menurut corak/desain tertentu akan memberikan perlindungan (dari gangguan alam, bencana, roh jahat dan lainlain), serta sebagai alat penghargaan bagi tamu (Yulianti \&Halan, 2015).

Dilihat dari kegunaannya, produk tenun ikat di Sumba Timur terdiri dari tiga jenis yaitu sarung, selimut dan selendang. Warna dasar tenunan pada umumnya adalah warna-warna dasar gelap, seperti warna hitam, coklat, merah hati dan biru tua, karena pengrajin tradisional selalu memakai zat warna nabati seperti tauk, mengkudu, kunyit dan tanaman lainya dalam proses pewarnaan benang, dan warnawarna motif dominan warna putih, kuning langsat, merah maron.

Untuk memproteksi keberadaan dan keberlanjutan tenun ikat, Pemerintah Provinsi Nusa Tenggara Timur mengeluarkan suatu kebijakan yang tercantum dalam ketentuan umum Bab 1 (satu), pasal 1 (satu), Ayat13 (Tigabelas) tentang pakaian Dinas danAtribut Pegawai Negeri Sipil di Lingkungan Pemerintahan Provinsi Nusa Tenggara Timur yang mewajibkan para Pegawai Negeri Sipil mengenakan tenun ikat motif daerah pada hari Rabu dan Kamis. Selain itu, terdapat dua himbauan Gubernur Nusa Tenggara Timur, yaitu memanfaatkan kain tenun ikat sebagai pemberian hadiah untuk para tamu dari luar Nusa Tenggara Timur dan mengenakan kain tenun ikat apabila berada di Nusa Tenggara Timur. Hal ini dilakukan agar kain tenun Nusa Tenggara Timur, lebih dikenal di luar daerah Nusa Tenggara Timur sebagai bentuk promosi (Yulianti \&Halan, 2015).

Melihat banyaknya fungsi kain tenun bagi masyarakat di Sumba Timur, terakhir ini banyak bermunculan usaha kecil dan usaha besar yang berbasis home industry pertekstilan tradisional sehingga menimbulkan persaingan antara perusahaan yang bergerak di bidang yang sama. Perusahaan home industry yang bermunculan di Sumba Timur menawarkan berbagai kain tenun dengan desain motif dan 


\section{Jurnal Komunikasi Nusantara}

e-ISSN. 2685-7650

Vol. 1 No. 2 (2019), pp 82-89

DOI: https://doi.org/10.33366/jkn.v1i2.24

ragam hias yang menarik dari daerah-daerah yang ada di Kabupaten Sumba Timur. Masyarakat di Pulau Sumba, NTT dan masyarakat di seluruh Indonesia adalah target utama dalam penjualan kain tenun dari beberapa perusahaan home industry. Kondisi tersebut mengharuskan perusahaan memiliki manajemen yang baik serta teknik pemasaran yang tepat. Teknik pemasaran yang tepat tidak dapat berjalan tanpa adanya komunikasi yang baik dari perusahaan yang nantinya akan disampaikan kepada konsumen, karena komunikasi dan pemasaran merupakan hal yang tidak dapat dipisahkan (Yantinus, 2016).

Penerapan strategi komunikasi pemasaran dilakukan oleh semua pelaku bisnis dengan melakukan bauran pemasaran (Marketing Mix). Bauran pemasaran merupakan cara di mana pengusaha dapat mempengaruhi konsumennya. Bauran pemasaran memerlukan perencanaan dan pengawasan yang matang serta perlu dilakukan tindakan-tindakan yang konkret. Untuk keperluan tersebut pengusaha dapat melakukan tindakan-tindakan yang terdiri dari 4 (empat) macam, yaitu tindakan mengenai product, price, place dan promotion (Daryanto 2011:168) dalam menawarkan produk atau jasa tidak terkecuali Sentra Tenun Prailiu. Terinspirasi dari fungsi dan kebutuhan masyarakat Sumba Timur akan kain tenun, Sentra Tenun Prailiu berdiri pada tanggal 28 November 2014 yang merupakan salah satu perusahaan yang bergerak di bidang home industry yang berada di Pulau Sumba. Sentra Tenun Prailiu menyediakan kain tenun Sumba Timur berupa selimut, sarung dan selendang. Di tahun pertama penjualan Sentra Tenun Prailiu mengalami peningkatan hal ini dipengaruhi oleh strategi komunikasi pemasaran yang tepat yang digunakan oleh Sentra Tenun Prailiu.

\section{Metode Penelitian}

Penelitian ini menggunakan metode kualitatif deskriptif. Emzir dalam Zainuddin (2017:12) mendefinisikan pendekatan kualitatif adalah prosedur untuk menghasilkan data-data secara deskriptif (penggambaran), yang meliputi kata-kata tertulis atau lisan dari orang-orang yang memahami obyek penelitian.

Penelitian dilaksanakan di Sentra Tenun Prailiu, Kelurahan Prailiu, Kecamatan Kambera, Kabupaten Sumba Timur, Provinsi Nusa Tenggara Timur. penentuan informan dalam penelitian ini dilakukan secara mendalam (Snawball Sampling). Snawball Sampling adalah teknik pengambilan sampel sumber data, yang pada awalnya berjumlah sedikit, semakin lama menjadi banyak (Sugiyono 2015:219). Dalam penelitian ini yang dijadikan informan adalah (Key-Informan) adalah sebagai berikut: (1) Pimpinan Sentra Tenun Prailiu: Rambu Ana. (2) Marketing pemasaran: Rambu Kudu. (3) Karyawan: Margaretha. (4) Konsumen: Umbu Ngaru.

Teknik pengumpulan data menggunakan teknik wawancara, observasi, dan dokumentasi. Sedangkan teknik analisis data menggunakan analisis dari Sutopo (2006:92) yang meliputi: reduksi data, sajian data dan verifikasi atau penarikan kesimpulan. Untuk mengukur validitas keabsahan data menggunakan trianggulasi sumber.

\section{Hasil dan Pembahasan}

\section{Strategi Pemasaran Sentra Tenun Prailiu dalam Meningkatkan Penjualan Kain Tenun Sumba Timur}

Pengembangan masyarakat adat didasarkan pada masyarakat lokal dan tidak merubah yang telah ada. Pada tahun 1998/1999 mulai terjadi krisis moneter. Penenun terpaksa berhenti menenun karena harga barang baku dipasar melonjak dari Rp. 200/tukal menjadi Rp. 1000/tukal. Akibat dari krisis moneter tersebut, maka timbul niat untuk menggali dan mengembangkan sumber-sumber penghasilan untuk mengatasi krisis, sekaligus mengatasi kemiskinan adalah dengan merevitalisasi tradisi menenun kain kapas asli dengan bahan pewarna asli yang hampir punah. Kegiatan ini juga 


\section{Jurnal Komunikasi Nusantara}

e-ISSN. 2685-7650

Vol. 1 No. 2 (2019), pp 82-89

DOI: https://doi.org/10.33366/jkn.v1i2.24

dimaksudkan untuk mengajak generasi muda agar kembali menekuni kerajinan leluhur mereka sebagai harta yang tidak dapat hilang begitu saja, sekaligus menempatkan kepemililikan kreatifitas kaum wanita Sumba Timur dan memperkuat posisi perempuan dalam lingkungan keluarga.

Sentra Tenun Prailiu merupakan salah satu perusahaan home industry yang bergerak dibidang pertekstilan tradisional yang memproduksi kain tenun Sumba Timur. langkah-langkah yang di tempuh oleh Sentra tenun prailiu adalah dengan melakukan eksperimen dengan menggunakan medote Return On Investment (ROI) dan pengetahuan asli atau kearifan lokal. Sentra Tenun Prailiu hadir sebagai perusahaan yang memiliki komitmen untuk menjaga, mengembangkan dan mendekatkan kain tenun Sumba Timur di dalam kehidupan sehari-hari masyarakat. Sentra Tenun Prailiu membutuhkan finansial yang besar untuk bisa mengembangkan perusahaan dan memberikan gaji kepada karyawan untuk melancarkan usahanya. Berangkat dari hal itu, Sentra Tenun Prailiu harus memiliki strategi pemasaran yang efektif dan inovatif sehingga mampu untuk membiayai aktifitas dalam perusahaan. Upaya-upaya untuk memperoleh keuntungan dan perkembangan perusahaan sangatlah penting, hal ini dapat dilihat dari aktivitas yang diikuti oleh Sentra Tenun Prailiu dalam program-program yang meniptakan perhatian publik akan kain Tenun Sumba Timur.

Usaha untuk meningkatkan jumlah penjualan kain tenun Sumba timur, Sentra Tenun Prailiu menerapkan strategi komunikasi pemasaran yang dapat diklasifikasikan antara lain, Product, Price, Place dan Promotion. Ini dilandasi atas hasil produk yang disediakan oleh Sentra Tenun Prailiu yang kreatif, unik dan berkualitas, sehingga dengan strategi komunikasi pemasaran yang digunakan bisa melancarkan atau meningkatkan jumlah penjualan kain tenun Sumba Timur.

Product yang dimaksudkan di sini merupakan produk tenun yang diproduksi dan dipasarkan oleh Sentra Tenun Prailiu. Produk yang disediakan oleh Sentra tenun Praliu berupa sarung, selendang, selimut, dan bandana yang diperoleh melalui hasil kerajinan tangan yang memiliki motif yang unik. Pemberian motif pada kain tenun Sumba Timur didasari oleh simbol kebutuhan adat istiadat dan budaya dari masyarakat Sumba Timur sekaligus sebagai tanda pengenal khusus orang Sumba Timur. Kain tenun sumba timur dikatakan asli apabila warnanya tidak pudar saat dicuci, halus dan berat saat digunakan.

Adapun motif yang dikembangan dalam perusahaan Sentra Tenun Prailiu adalah: Pertama, motif manusia memegang parang dan tombak, motif ini mengartikan bahwa manusia di Sumba Timur melakukan peperangan dan berburu. Kedua, motif Mamuli, Mamuli dalam motif ini melambangkan perempuan yang dibelis, selain itu mamuli juga harus disiapkan oleh laki-laki apabila hendak meminang seorang perempuan. Ketiga, ada motif hewan, motif ini melambangkan bahwa masyarakat di Sumba Timur bercocok tanam, selain itu motif ini melambangkan bahwa untuk meminang seorang perempuan harus menyediakan hewan.

Price (harga) merupakan salah satu bagian yang sangat penting dalam pemasaran suatu produk karena harga adalah satu dari empat bauran pemasaran (4P) Product, price, place promotion. Harga merupakan salah satu penentu keberhasilan suatu perusahaan karena harga menentukan seberapa besar keuntungan yang akan diperoleh perusahaan dari penjualan produknya baik berupa barang maupun jasa, karena ketika penetapan harga terlalu tinggi akan menyebabkan penjualan menurun, namun jika harga terlalu rendah akan mengurangi keuntungan yang dapat diperoleh oganisasi atau perusahaan. Adapun harga yang disedikan oleh Sentra Tenun Prailiu bervariatif yang dimulai dari harga Rp.50.000Rp.3.000.000 harga tersebut dipertimbangkan dengan biaya produksi dan bahan yang digunakan.

Place (Tempat) merupakan hal yang harus di perhatikan oleh pelaku bisnis, karena berkaitan dengan berjalannya suatu usaha dalam memasarkan produk untuk mendorong kelancaran suatu bisnis. Dalam pemilihan tempat Sentra Tenun Prailiu memilih pasar untuk melakukan penjualan. Karena 


\section{Jurnal Komunikasi Nusantara}

e-ISSN. 2685-7650

Vol. 1 No. 2 (2019), pp 82-89

DOI: https://doi.org/10.33366/jkn.v1i2.24

tempat tersebut dinilai tepat dan strategis untuk dijangkau oleh pelanggan ataupun calon konsumen. Dalam hal ini dibuktikan dengan adanya cabang-cabang Sentra Tenun Prailiu yang berada di pusatpusat Kota di Pulau Sumba.

Promotion (Promosi) adalah koordinasi dari seluruh upaya yang dimulai pihak penjualan untuk membangun berbagai saluran informasi dan persuasi untuk menjual barang dan jasa untuk memperkenalkan suatu gagasan. Promosi yang dilakukan oleh Sentra Tenun Praili ada 2 (dua) yaitu promosi penjualan (sales promotion) dan penjualan perorangan (personal selling). Kedua promosi tersebut merupakan salah satu upaya untuk bisa meningkatkan penjualan kain tenun Sumba Timur untuk memperoleh keuntungan, karena menyediakan produk yang bagus dan berkualitas tidak cukup untuk bisa bertahan dan bersaing di pasaran sehingga dibutuhkan strategi promosi yang baik dan tepat. (1) Sales promotion merupakan usaha untuk mempengaruhi konsumen dalam kegiatan pembelian sesuai keinginan dan kebutuhannya. Bagian penjualan atau pemasaran dari suatu perusahaan atau organisasi akan mengembangkan promosi untuk menginformasikan produk mereka sehingga dapat mempengaruhi konsumen untuk membeli produk yang ditawarkan. Promosi penjualan yang dilakukan oleh Sentra Tenun Prailiu adalah dengan memberikan bonus kepada konsumen yang membeli kain tenun lebih dari 3 (tiga) lembar. Bonusnya berupa bandana dan selendang. Selanjutnya Sentra tenun juga melayani jasa sewah kain tenun dengan harga Rp. 100.000/hari. Promosi penjualan ini peminat biasanya berasal dari kalangan artis yang sedang syuting film atau pembuatan video clip. (2) Personal Selling merupakan bagian dari kegiatan promosi, yaitu cara untuk memperkenalkan dan menarik minat konsumen terhadap produk yang ditawarkan secara tatap muka. Penjualan tatap muka yang dilakukan oleh Sentra Tenun Prailiu yaitu dengan melakukan kerja sama dan mengikuti event-event seperti pameran dan juga festival yang dilakukan oleh pemerintah Kabupaten Sumba Timur. Hal ini dilakukan agar bisa menjaring konsumen dan calon konsumen untuk tetap tertarik pada kain tenun yang diproduksi Sentra Tenun prailiu.

Setiap organisasi atau perusahaan yang ingin berhasil dalam pemasaran harus terlebih dahulu memiliki suatu rencana pemasaran strategis (strategic marketing plan) yang berfungsi sebagai panduan dalam menggunakan sumber daya yang dimiliki (Yantinus, 2016). Seperti yang kita ketahui bersama bahwa strategi pemasaran ditentukan berdasarkan analisis situasi, yaitu suatu studi terperinci mengenai kondisi pasar yang dihadapi perusahaan. Berdasarkan situasi ini Sentra Tenun Prailiu mencoba memahami pasar yang mencakup peluang pasar dan tingkat persaingan di dalamnya.

Market opportunities atau peluang pasar adalah wilayah di mana terdapat kecenderungan permintaan yang menguntungkan. Dalam hal ini perusahaan percaya bahwa kebutuhan konsumen belum terpenuhi dan bagaimana cara perusahaan bersaing dengan cara yang efektif. Peluang pasar merupakan kebutuhan dalam suatu usaha seperti pada Sentra Tenun Prailiu. Selain kekuatan yang harus dimiliki dalam suatu usaha, peluang pasar juga menjadi tolak ukur bagi pelaku bisnis sehingga dapat memasarkan produknya di pasaran sesuai dengan tujuan yang dicapai. Adapun yang menjadi peluang pasar bagi Sentra Tenun Prailiu saat ini adalah meningkatnya kebutuhan masyarakat akan kain tenun Sumba Timur, sehingga hal ini menjadi peluang terbesar bagi mereka untuk memasarkan produknya.

Competitive advantage atau keuntungan kompetitif yaitu satu hal khusus yang harus dimiliki atau dilakukan perusahaan yang memberikan keunggulan dibandingkan kompetitor. Contoh kemampuan kompetitif ini antara lain adalah kemampuan perusahaan untuk memproduksi barang dan jasa berkualitas tinggi, memberikan pelayanan yang baik, memproduksi dengan ongkos yang rendah sehingga haga produk menjadi lebih murah Morissan (2010:53). Adapun kompetitor dari Sentra Tenun Prailiu adalah ole-ole blessing sumba, marapu heaven, dan marapu aksesories. Perusahaan-perusahaan 


\section{Jurnal Komunikasi Nusantara}

e-ISSN. 2685-7650

Vol. 1 No. 2 (2019), pp 82-89

DOI: https://doi.org/10.33366/jkn.v1i2.24

tersebut menyediakan produk yang sama dengan harga yang lebih murah dari pada harga kain tenun yang dijual oleh Sentra Tenun Prailiu.

Saat ini sangat jarang untuk menemukan suatu merek atau produk yang dapat memuaskan kebutuhan seluruh konsumen. Hal ini menjadi dorongan bagi perusahaan untuk mengembangkan strategi pemasaran yang berbeda untuk memuaskan kebutuhan berbagai konsumen yang memiliki pendapat berbeda. Sentra Tenun Prailiu dalam memilih atau menentukan pasar dengan melakukan proses pemasaran yang terdiri dari segmentasi pasar, memilih pasar yang akan dijadikan target dan menentukan positioning produk melalui strategi pemasaran. Berikut ini adalah penjelasan dari proses pemasaran yang digunakan oleh Sentra Tenun Prailiu dalam meningkatkan penjualan kain tenun Sumba Timur:

Segmentasi pasar adalah kegiatan membagi-bagi pasar yang bersifat umum dari suatu produk kedalam satuan pasar atau segmen pasar yang bersifat khusus. Segmen pasar terdiri dari sekelompok pelanggan yang memiliki sekumpulan kebutuhan dan keinginan yang serupa, Kotler dan Amstrong (2006:121). Segmentasi pasar diperlukan agar perusahaan dapat melayani konsumennya secara lebih baik, melakukan komunikasi yang lebih perusasif dan yang terpenting adalah memuaskan kebutuhan dan keinginan konsumen yang dituju. Segmentasi pasar dari Sentra Tenun Prailiu berdasarkan kebutuhan adalah masyarakat yang menyadari bahwa mereka membutuhkan atau menyukai kain tenun, sedangkan segmentasi geografisnya adalah dengan membidik pusat keramaian (pasar dan destinasi wisata). Dan jika ditinjau dari segi usia, target yang dibidik mencakup usia kanak-kanak, remaja, dewasa, dan lansia yang menggemari kain tenun Sumba Timur, sedangkan berdasarkan jenis kelamin adalah dari kalangan laki-laki dan perempuan.

Targetting merupakan proses berkelanjutan dari segmentasi di mana setelah dilakukan pemelihan daerah lokasi sasaran pasar, maka langkah selanjutnya adalah memilih pasar sasaran yang dirasa cocok dan tepat untuk dijadikan sasaran. Menurut Tjiptono (2012:162) targetting merupakan proses mengevaluasi dan memilih satu atau beberapa segmen pasar yang dinilai menarik untuk dilayani dengan program pemasaran yang spesifik perusahaan. Sentra Tenun Prailiu memilih beberapa pasar untuk dijadikan target pemasaran produk, yaitu Pasar Waingapu, Pasar Prailiu, Pasar Lama Waingapu, Pasar Waibakul, Pasar Waikabubak, Pasar Waitabula dan beberapa destinasi wisata.

Positioning adalah strategi merebut posisi di benak konsumen. Strategi ini menyangkut bagaimana membangun kepercayaan, keyakinan, dan kompetisi bagi pelanggan. Penentuan pasar dalam strategi pemasaran merupakan salah satu hal utama dalam menciptakan atau mempertahankan loyalitas konsumen dengan cara meningkakan kualitas produk.

\section{Faktor-Faktor yang Mempengaruhi Kegiatan Pemasaran Sentra Tenun Prailiu}

Sentra Tenun Prailiu berdasarkan struktur organisasi memiliki bagian pemasaran yang bertanggung jawab secara khusus tentang pemasaran yang akan dilakukan oleh perusahaan. Ini adalah wujud sikap dari perusahaan Sentra Tenun Prailiu atas komitmen yang dibangun yaitu meningkatkan penjualan kain tenun dan mendekatkan kain tenun Sumba Timur dalam kehidupan sehari-hari masyarakat. Namun kendala bagi perusahaan ini adalah proses pemasaran yang tidak lancar. Bertolak dari alasan tersebut, Sentra Tenun Prailiu yang berada di bawah koordinasi Rambu Ana, berusaha untuk membangun kerja sama dengan berbagai pihak, salah satunya adalah lembaga pemerintah yang sampai saat ini masih memberikan perhatian.

Adapun kendala yang dihadapi Sentra Tenun Prailiu dalam melakukan pemasaran untuk meningkatkan penjualan kain tenun Sumba Timur, yang pertama ada faktor pendukung dan yang kedua 


\section{Jurnal Komunikasi Nusantara}

e-ISSN. 2685-7650

Vol. 1 No. 2 (2019), pp 82-89

DOI: https://doi.org/10.33366/jkn.v1i2.24

ada faktor penghambat. Dari dua faktor tersebut diklasifikasikan ke dalam dua lingkungan yaitu lingkungan internal dan eksternal perusahaan.

Faktor pendukung internal yaitu segala bentuk dukungan berupa perilaku, tindakan yang datangnya dari dalam lingkungan perusahaan itu sendiri. Faktor pendukung dari dalam perusahaan Sentra Tenun Prailiu yang pertama datangnya dari karyawan, keluarga dan orang-orang yang terlibat dalam perusahaan tersebut. Dukungan yang diperoleh ini berupa kerja sama dan pengetian yang baik antara pimpinan dan karyawan. Sedangkan faktor pendukung dari luar perusahaan yaitu dukungan berupa tindakan atau perilaku yang diperoleh dari dalam perusahaan. Dukungan eksternal perusahaan Sentra Tenun Prailiu berupa sumbangan untuk pengembangan perusahaan yang diperoleh dari pemerintah dan konsumen atau pelanggan.

Faktor penghambat internal yaitu hambatan yang datang dari dalam perusahaan sehingga mengganggu kegiatan yang dilakukan perusahaan. Faktor penghambat internal Sentra Tenun Prailiu yang pertama datangnya dari karyawan yang kurang memiliki motivasi kerja sehingga produksi kain tenun Sumba Timur tidak mencapai target. Yang kedua perusahaan sering mengalami kekurangan bahan yang digunakan oleh perusahaan untuk membuat kain tenun. Hal ini dikarenakan bahan yang digunakan oleh Sentra Tenun Prailiu diperoleh dari alam yang kadang hanya berada pada musim-musim tertentu saja. Sedangkan faktor penghambat eksternal Sentra Tenun Prailiu dipengaruhi oleh adat istiadat dan budaya yang berlangsung dilingkungan perusahaan tersebut. Salah satu contoh faktor budaya yang menjadi penghambat adalah pesta adat atau kematian yang memakan waktu cukup lama. Hal ini mempengaruhi aktifitas karyawan Sentra Tenun Prailiu menjadi tidak stabil dan bahkan proses produksi tidak dilakukan sama sekali. Faktor penghambat yang kedua dipengaruhi oleh konsumen yang sering membatalkan kerja sama atau pembelian kain tenun Sumba Timur. Hal ini menjadi kendala untuk bisa meningkatkan penjualan kain tenun Sumba Timur pada perusahaan Sentra Tenun Prailiu.

\section{Kesimpulan}

Hasil penelitian menunjukan bahwa upaya Sentra Tenun Prailiu dalam meningkatkan penjualan kain tenun Sumba Timur adalah dengan melakukan strategi komunikasi pemasaran yang meliputi produk, harga, tempat dan promosi. Produk yang disediakan oleh Sentra tenun Praliu berupa sarung, selendang, selimut, dan bandana yang diperoleh melalui hasil kerajinan tangan masyarakat dan memiliki motif yang unik serta harga yang bervariasi dan disesuaikan dengan proses produksi. Selain itu tempat dan promosi yang digunakan yakni promosi penjualan (sales promotion) dan penjualan perorangan (personal selling).

Dalam melakukan strategi komunikasi pemasaran untuk meningkatkan penjualan, Sentra Tenun Prailiu dipengaruhi oleh faktor pendukung dan faktor penghambat. Faktor pendukung didapat dari lingkungan perusahaan, karyawan dan sumbangan pengembangan dari pemerintah. Sedangkan faktor penghambat berupa sulitnya bahan alam untuk pembuatan tenun serta adanya pembatalan kerja sama yang dilakukan konsumen dengan Sentra Tenun Prailiu.

\section{Daftar Pustaka}

Daryanto. (2011). Manajemen Pemasaran. Bandung : CAPS

Emzir. (2010). Metode Penelitian Kualitatif. Jakarta: PT. Rajagrafindo

Kotler,Philip. (2008). Manajemen Pemasaran. Jakarta: Prenada

Maryanto, T. \& Syahida, A.R. (2019). Strategi Komunikasi Pemasaran dalam Meningkatkan Hasil Penjualan di Kampung Keramik Dinoyo Kota Malang. Jurnal Komunikasi Nusantara, 1 (1), 36-42. 


\section{Jurnal Komunikasi Nusantara}

e-ISSN. 2685-7650

Vol. 1 No. 2 (2019), pp 82-89

DOI: https://doi.org/10.33366/jkn.v1i2.24

Morissan. (2010). Periklanan Komunikasi Pemasaran Terpadu. Jakarta: Pemada

Sutisna. (2002). Komunikasi Pemasaran. Yogyakarta. Amus

Sugiyono. (2016). Metode Penelitian Pendidikan Kualitatif, Dan R\&D: Bandung Alfabeta

Sutopo. (2005). Metodologi Penelitian Kualitatif Edisi Kedua Surakarta: Graha Ilmu

Tjiptono, Fandy. (2001). Strategi Pemasaran. Yogyakarta: Andi Ofset.

Yulianti, Halan, V.R. (2015). Usulan strategi pemasaran Tenun Ikat Kupang Berdasarkan Tingkat Kepentingan Konsumen dengan Metode Cluster analysis., Jurnal Integrasi, 5 (1), 102-118.

Yantinus,Tani. (2016). Strategi Komunikasi Pemasaran Dalam meningkatkan Jumlah Pembeli Kain

Tenun Ikat Biboki. Jurnal Ilmu Sosial dan Ilmu Politik, 5 (3), 97-103. 